\title{
A Magyar Hadtudományi Társaság tudományos konferenciája a haditechnikai kutatás-fejlesztésről
}

A Magyar Hadtudományi Társaság 2019. november 5-én tartotta a „Kutatás, fejlesztés és innováció a hazáért" című tudományos konferenciáját a Stefánia Palota Honvéd Kulturális Központban. A konferencia célja a haderő modernizációjának bemutatása, a kutatás, fejlesztés és innováció új rendszerének megismertetése, a NATO-követelmények és a jövőbeli perspektívák értékelése volt.

A tudományos konferencián adta át a Magyar Hadtudományi Társaság elnöke, prof. dr. Szenes Zoltán ny. vezérezredes a társaság tudományos diját, a Tanárky Sándor Dijat, prof. dr. Óvári Gyula okleveles mérnök ezredesnek. Óvári professzor a katonai-müszaki tudomány kandidátusa, a Nemzeti Közszolgálati Egyetem egyetemi tanára. Egy évtizeden keresztül volt a Zrínyi Miklós Nemzetvédelmi Egyetem Repülőműszaki Intézet, majd a Repülő és Légvédelmi Intézet igazgatója. Különböző tisztségeket töltött be a Magyar Tudományos Akadémia bizottságaiban, tagja a MTA IX. Osztály Hadtudományi Bizottságának. Az NKE Katonai Műszaki Doktori Iskolájának alapító tagja. Óvári professzor évtizedeken kerszetül töltötte be a Magyar Hadtudományi Társaság Légierő Szakosztályának elnöki tisztségét. 2019-ben elnyerte a Magyar Hadtudományi Társaság Érdemes tag elismerését. Prof. dr. Óvári Gyula Tanárky Sándor díjhoz kötődő laudációját - egykori tanítványaként - az MHTT Légierő Szakosztályának elnöke, a Haditechnika tudományos folyóirat felelős szerkesztője, dr. Hegedűs Ernő mk. alezredes tartotta. A díj átadását követően prof. dr. Óvári Gyula ny. ezredes „Katonai eszközök a világürben" címmel tartott előadást, kitérve arra, hogy a NATO 2016-ban haderőnemi szintre emelte az ürhadviselést.

A tudományos konferencia részét képezte a Magyar Hadtudományi Társaság NATO20 projektjének, így számos előadás reflektált hazánk NATO-tagságára és az utóbbi két

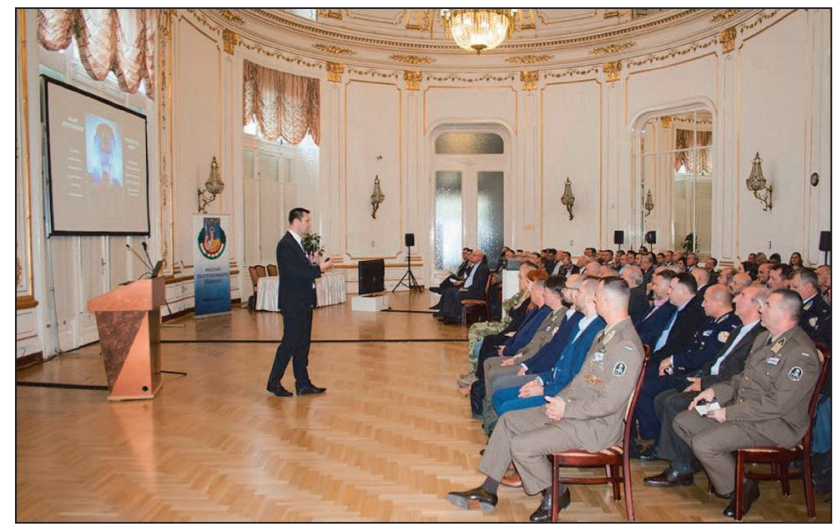

1. ábra. Dr. Porkoláb Imre ezredes - a Nemzeti Fegyverzeti Igazgató Kutatás-Fejlesztésért felelös helyettese - „A haderő megújítása és az MH Modernizációs Intézet" címmel tartotta konferencianyitó előadását (Fotó: MHTT)

évtized során a szövetséggel együttmúködésben elért haditechnikai kutatás-fejlesztési eredményekre.

Dr. Porkoláb Imre ezredes - a Nemzeti Fegyverzeti Igazgató Kutatás-Fejlesztésért felelős helyettese, a Haditechnika műszaki-tudományos és ismeretterjesztő folyóirat szerkesztőbizottságának elnöke - nyitó előadásával vette kezdetét a „Kutatás, fejlesztés és innováció a hazáért” című tudományos konferencia. Az első előadó „A haderő megújítása és az MH Modernizációs Intézet" címmel tartotta meg előadását. Amint azt dr. Porkoláb ezredes előadásában elmondta, 2019. január 1-jétől a hazai haditechnikai kutatás-fejlesztés ismét intézeti keretek között zajlik, mivel létrejött az e terület képviseletéért felelős MH Modernizációs Intézet. Az Intézet az MH védelmi innovációs képességének fejlesztése,
ÖSSZEFOGLALÁS: A Zrínyi 2026 Honvédelmi és Haderőfejlesztési Program egyszerre tűzte célul a haderő korszerüsítését, illetve a magyar hadiipar élénkítését. A magyar hadiipar fejlesztéséhez azonban hatékony haditechnikai kutatás-fejlesztési háttér szükséges. Ennek támogatása érdekében a Magyar Hadtudományi Társaság „Kutatás, fejlesztés és innováció a hazáért” címmel szervezett tudományos konferenciát 2019. november 5-én a Stefánia kulturális központban.

KULCSSZAVAK: haditechnikai K+F, Magyar Hadtudományi Társaság, Zrínyi 2026 haderőfejlesztési program
ABSTRACT: The Zrínyi 2026 Defence and Armed Forces Development Program set the goal of modernizing the armed forces and stimulating the Hungarian military industry at the same time. However, the development of the Hungarian military industry requires an effective military technical research and development background. To support this, the Hungarian Military Science Society organized a scientific conference entitled "Research, Development and Innovation for the Homeland" on November 5 at the Stefánia Cultural Centre.

KEY WORDS: military technical research and development, Hungarian Military Science Society, Zrínyi 2026 Defence and Armed Forces Development Program

Mérnök alezredes PhD, NKE Hadtudományi és Honvédtiszképző Kar, Haditechnikai Tanszék. MHTT Légierő Szakosztály elnök.

ORCID: 0000-0001-8457-5044

** Újságíró, a Haditechnika folyóirat szerkesztője. ORCID: 0000-0003-2442-3051 


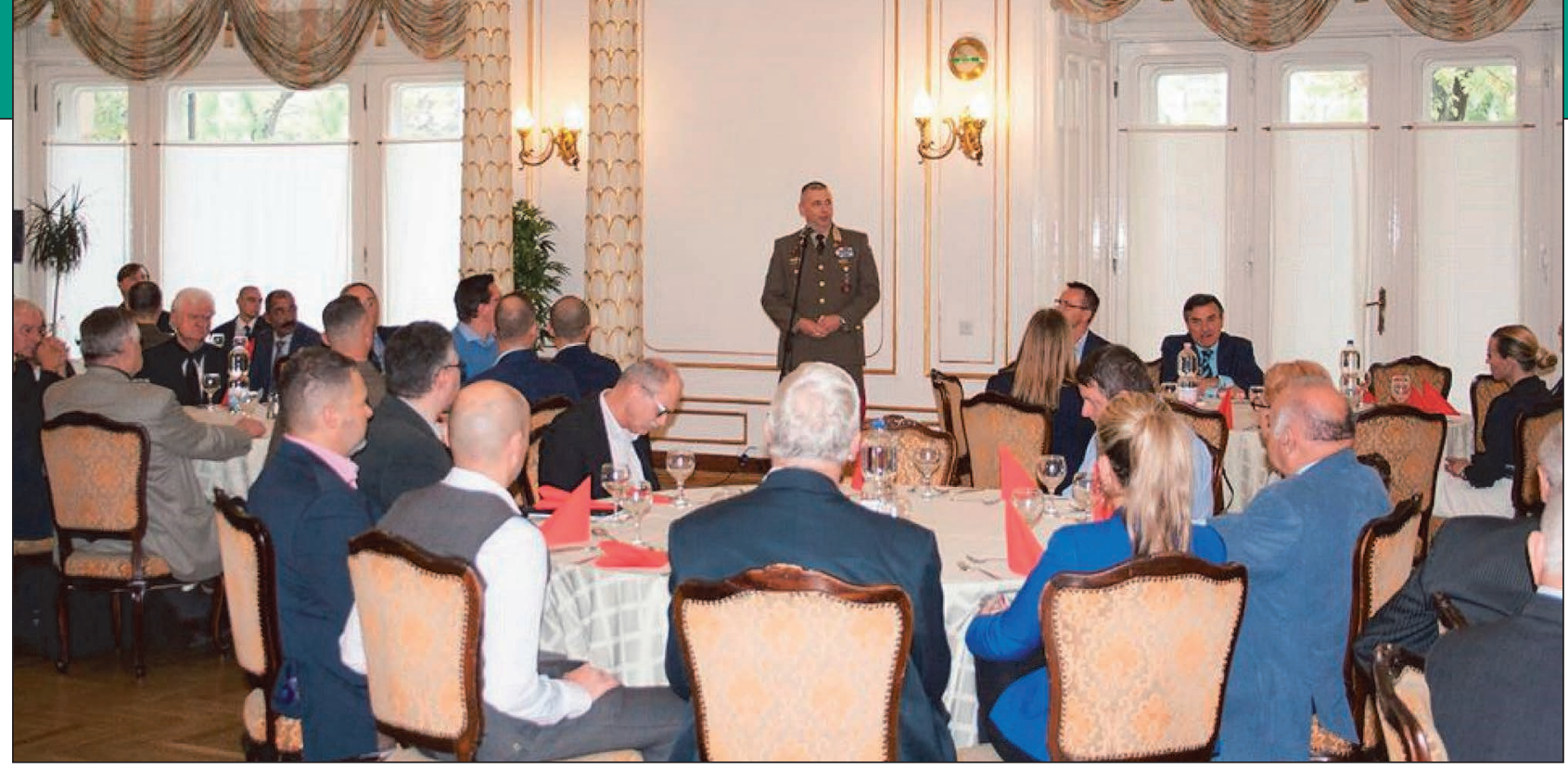

2. ábra. Dr. Ruszin Romulusz dandártábornok, a Honvédelmi Minisztérium Miniszteri Titkárság vezetője a Magyar Hadtudományi Társaság „Kutatás, fejlesztés és innováció a hazáért” című konferenciáján (Fotó: MHTT)

a haditechnikai kutatás-fejlesztéssel kapcsolatos feladatok centralizálása, továbbá a védelmi ipari fejlesztéssel összefüggő hadfelszerelés-fejlesztési feladatok ellátása hatékonyságának növelése érdekében, az MHP parancsnokának közvetlen szolgálati alárendeltségében jött létre. Az MH Modernizációs Intézet vezetés-irányítási rendszere oly módon kerül tervezésre, hogy a nemzeti hadfelszerelési igazgató feladataival összefüggő egyes szakmai feladatainak irányítása az MHP parancsnoka útján megvalósíthatóvá váljon. A szervezet kutatói alaprendeltetésből fakadó kutatás-fejlesztési feladataik kapcsán folyamatosan tartják a kapcsolatot a hazai és külföldi kutatóintézetekkel, a Magyar Tudományos Akadémia, a NATO Kutatás és Technológia Szervezet (NATO STO) és az Európai Védelmi Ügynökség (EDA) szervezeteivel, illetve a felsőoktatási intézményekkel. Széles körű publikációs tevékenységet folytatnak magyar és idegen nyelvű tudományos folyóiratokban.

Prof. dr. Ráth Tamás, ny. ezredes „A NATO és a tudomány - hazai eredmények" címmel tartott előadást, visszatekintve a 1997. augusztus - 2007. december közötti időszakra, amikor a Haditechnikai Intézet, majd a Haditechnikai Hivatal főigazgatója volt. Amint elmondta, minden NATO-tagország legfeljebb három fővel képviseltetheti magát a NATO Kutatási és Technológiai Tanácsban (Research and Technology Board - RTB) és az RTO (Research Technology Organisation) panelekben. A képviselők személye célszerüen a kormányzati (védelmi), az ipari vagy a felsőoktatási szférából kerül ki. Az RTO dolgozta ki a NATO kutatási és technológiai stratégiáját.

Dr. Ruszin Romulusz dandártábornok, a Honvédelmi Minisztérium Miniszteri Titkárság vezetője (2020. márciusa óta a Honvédelmi Minisztérium helyettes államtitkára - a szerk.), a Magyar Hadtudományi Társaság Korponay-dijas kutatója, a Haditechnika tudományos folyóirat szerkesztőbizottságának tagja köszöntötte a konferencia résztvevőit és a NATO doktrínák a haderőre és - ezzel áttételesen - a haditechnikai kutatás-fejlesztésre gyakorolt hatásáról beszélt.

A biztonságpolitika és haderőfejlesztés szekcióban tartotta előadását „A NATO előtt álló kihívások és lehetőségek a Szövetség decemberi csúcstalálkozója előtt” címmel dr. Balogh István, a KKM biztonságpolitikáért felelős helyettes államtitkára. „A NATO a változó nemzetközi biztonsági környezetben" címmel adott elő dr. Tálas Péter, az NKE SVKI, igazgatója. Ezt követte „A NATO szerepe a poszt-vesztfáliai rendszerben" című előadásával dr. Gyarmati István nagykövet, CEID (Centre for Euro-Atlantic Integration and Democracy - Euro-Atlanti Integrációért és
Demokráciáért Alapítvány) elnöke. A délutáni ülésszakban számos további érdekfeszítő előadás hangzott el a NATO kollektív védelem és béketámogató műveletek kapcsolatának fejlődéséről, az Észak-atlanti Tanács működéséről, illetve a biztonság globális és európai összefüggéseiről.

A konferencia címének megfelelően önálló szekció foglalkozott a haditechnikai kutatás-fejlesztés és a hadiipar kérdéseivel. Itt szó esett a sikeres $\mathrm{K}+\mathrm{F}$ zálogáról, a teljeskörű innovációról, illetve a magyar védelmi ipar helyzetéről és fejlődési lehetőségeiről, továbbá a Gripen vadászrepülőgép ellentételezési programjának tapasztalatairól is. Különösen érdekfeszítő volt dr. habil. Fűrész József egyetemi magántanár előadása a „Mobil telepíthető, megerősített, molekuláris biológiai laboratórium" tárgyában, illetve a napjaink haditechnikai kutatás-fejlesztésének egyik fő áramát képező „Autonóm járművek kutatási kihívásai a jövőben" című - dr. Vanek Bálint tudományos főmunkatárs, a SZTAKI kutató laborvezető helyettese által megtartott - előadás is. A haditechnika szekciót záró szakmai beszélgetés során felszólalt Zsitnyányi Attila, a Védelmi Ipari Szövetség elnöke. Elmondta, hogy 6 éve vezeti az immár negyed évszázada működő szövetséget. A hazai hadiipar jelenleg mintegy 40 millió Euro éves exportteljesítményre képes, amely - a Zrínyi 2026 haderő fejlesztési program hadiipar-fejlesztési törekvéseinek hatására a jövőben a szövetség tagságát alkotó 34 hadiipari vállalat reményei szerint dinamikusan növekedni fog.

Önálló szekció tárgyalta a modernizáció és humánpolitika, illetve a honvédelmi média kérdéseit is. Utóbbi témában különösen érdekfeszítő volt az MHTT Légierő Szakosztály tagjának, Zord Gábor Lászlónak, a Miniszterelnöki Kormányiroda Nemzeti Védelmi Ipari és Védelmi Célú Fejlesztésekért, valamint a Haderő-modernizáció Koordinálásáért Felelős Kormánybiztos Titkársága munkatársának „Információs műveletek a Zrínyi 2026 támogatására” című előadása. Dr. Bokodi-Oláh Gergely, a HM Zrínyi Térképészeti és Kommunikációs Szolgáltató Közhasznú Nonprofit Korlátolt Felelősségű Társaság kommunikációs ágazati igazgatója a cég tevékenységének teljeskörü bemutatására vállalkozott. A hagyományosnak tekinthető könyv- és lapkiadási, valamint nyomdaipari feladatok mellett a társaság működteti a katonai filmstúdiót, a honvedelem.hu hírportált, valamint a honvédségi vezetői állomány számára szakembereik tartják a médiakezelési tréningeket. A szekció záró előadását Krizbai Diána, az MTI Junior Príma-díjas honvédelmi tudósítója, „A honvédelem ügye a hírekben” címmel tartotta. 